\title{
Effect of Cocaine in Early Gestation on Striatal Dopamine and Neurotrophic Activity
}

\author{
DEBRA E. WEESE-MAYER, JEAN M. SILVESTRI, DONGHUI LIN, COLLEEN M. BUHRFIEND, \\ ERWIN S. LO, AND PAUL M. CARVEY \\ Departments of Pediatrics [D.E.W-M., J.M.S.]. Neurolegical Sciences [D.L., C.M.B., E.S.L., P.M.C.], and \\ Pharmacology' /C.M.B., E.S.L., P.M.C.J. Rush Medical College, Rush University, Rush-Presbyterian-St. Luke's \\ Medical Center, Chicago, Illinois 60612
}

\begin{abstract}
Prenatal exposure to the dopamine (DA) agonist cocaine, even if limited to early gestation, is associated with impaired developmental outcome in the human infant. We investigated the possible role of neurotrophic factors in this process by evaluating 4- to 6-d-old New Zealand White rabbit pups $(n=14)$ born to cocaineexposed does $(30 \mathrm{mg} / \mathrm{kg} / \mathrm{d}$ s.c. from days 7 to 15 of a $32-d$ gestation) and control does (sterile $\left.\mathrm{H}_{2} \mathrm{O}\right)$. Cocaine exposure reduced striatal dopamine by $46 \%(t=2.31 ; p<0.05)$ and striatal 3,4-dihydroxyphenyl acetic acid by $49 \%(t=2.44$; $p<0.05$ ). The number of neuron-specific enolase immunoreactive neurons in mesencephalic cultures incubated with striatal extracts from pups exposed to cocaine was reduced by $61 \%$ relative to the effect of striatal extracts from control pups $(t=4.84 ; p<0.01)$. The present results suggest that the reduction in striatal dopamine observed may result from a cocaine-induced decrease in striatal trophic activity. (Pediatr Res 34: 389-392, 1993)
\end{abstract}

\section{Abbreviations}

DA, dopamine

DOPAC, 3,4-dihydroxyphenyl acetic acid

E, embryonic

$P$, postnatal

HBSS, Hanks' balanced salt solution

TBS, Tris-buifered saline

NSE, neuron-specific enolase

NSEir, NSE immusoreactive

Prenatal exposure to the DA agonist cocaine is associated with impaired developmental outcome in the human infant (1-9). Reported observations include a broad spectrum of abnormalities. However, variability in study methodology, patient populations, and dose, duration, and gestational timing of cocaine exposure prevent a clear understanding of the specific relationship of cocaine to the type and severity of impairment. Mechanisms that may be responsible for the altered developmental outcorne after prenatal cocaine exposure remain elusive. Although speculated, the role of neurotransmitters has not been thorcughly investigated in the human infant. However, recent studies of the DA system of maturing rodents after in utero

Received for rapid publication June 14, 1993; accepted June 25, 1993.

Correspondence and reprint requests: Debra E. Weese-Mayer, M.D., Associate Professor of Pediatrics, Rush-Presbyterian-St. Luke's Medical Center, 1653 W. Congres:s Parkway. Chicago, IL 60612.

Supported in part by grants from the National Institutes of Health (biomedical research support Grant BRSG SO7 RR05477), division of research resources (RushPresbyterian-St. Luke's Medical Center), the Otho Sprague Foundation, the Associates Board, and the United Parkinson Foundation. cocaine exposure document a depletion of striatal DA content and other indices of DA neurotransmission (10-12).

We have previously developed animal models to investigate the effect of prenatal cocaine on postnatal growth (13) and the ventilatory (14) and physiologic responses to postnatal hypoxia in the newborn rabbit (15). We have also shown that chronic treatment with other dopamine agonists reduces striatal dopamine content as well as striatal trophic activity $(16,17)$. Based on these clinical and animal observations, we sought to investigate the relationship between dopamine and striatal trophic activity in the newborn after in utero cocaine exposure in our animal model.

\section{MATERIALS AND METHODS}

Study design. The study design included six New Zealand White rabbit does among cocaine-treated $(\mathrm{CC})$ and control $(\mathrm{VEH})$ groups. No restriction was placed on food or water intake. Approval was obtained from the Institutional Animal Care and Use Committee.

Rabbits were mated on $\mathrm{d} 0$ of timed gestation. Because the rabbit ovum does not implant until $\mathrm{d} 7$ of gestation (18), injection did not begin until d 7 to avoid interference with ovum implantation. To provide the equivalent of early gestation cocaine exposure, a daily s.c. injection of $30 \mathrm{mg} / \mathrm{kg}(0.089 \mathrm{mmol} / \mathrm{kg})$ cocaine $\mathrm{HCl}$ (Mallinckrodt, St. Louis, MO) in 10\% solution with sterile water was administered to each cocaine-treated doe and a matched volume of sterile water to each control doe from $\mathrm{d} 7$ through 15 of a $32-d$ gestation. Cocaine was prepared fresh daily. The injection site was rotated daily to avoid tissue necrosis.

Population and general procedures. Fourteen New Zealand White rabbit pups ( $7 \mathrm{CC}, 7 \mathrm{VEH})$ born to the six does were studied between 4 and $6 \mathrm{~d}$ of age. Mean pup weights were $89 \pm$ $14 \mathrm{~g}$ (CC) and $82 \pm 19 \mathrm{~g}$ (VEH) (NS). The pups were lightly anesthetized with halothane $(4 \%)$ and subsequently exsanguinated by perfusion. The brain was then removed, immersed in liquid methylbutane for $90 \mathrm{~s}$, wrapped in aluminum foil, and stored at $-80^{\circ} \mathrm{C}$.

Specimen preparation. For tissue dissection, the brain, still frozen, was mounted on a cryostat chuck and $750-\mu \mathrm{m}$-thick coronal sections were cut starting at the rostrum of the striatum. A tissue punch ( $1.0 \mathrm{~mm}$ internal diameter) was taken from the center of the striatum in the second coronal section and homogenized, and the supernatant was passed to HPLC for analysis of DA and its metabolite DOPAC (19). The pellet was resuspended in $1.0 \mathrm{~N} \mathrm{NaOH}$ and assessed for total protein as previously described (19). The remainder of the striatum was then dissected from each coronal section using a "knife and fork" technique. The tissue was homogenized in HBSS $(40 \mathrm{mg}$ wet weight $/ \mathrm{mL}$ HBSS) and the supernatant "extract" assessed for total protein using a protein assay kit (Bio-Rad Laboratories, Richmond, CA) $(16,20)$. A section of cerebellum was similarly processed. All 
extracts were then diluted with HBSS to yield an equivalent protein content across all samples. Aliquots were taken and stored at $-80^{\circ} \mathrm{C}$ for subsequent assessment of trophic activity.

Dissociated, primary rostral rat mesencephalic tegmentum cultures were plated out in 96-well Falcon plates (3500 cells/ $\mathrm{cm}^{2}$; Becton Dickinson, Oxnard, CA) and grown in defined media as previously described $(16,21)$. Fifty $\mu \mathrm{L}$ of the striatal and cerebellar extracts from each animal were added to the cultures within $1 \mathrm{~h}$ of plating. Each extract was added to four experimental wells on two separate plates. Each plate also contained a protein control (four wells incubated with an equivalent quantity of BSA in $50 \mu \mathrm{L}$ of HBSS and $450 \mu \mathrm{L}$ of defined media) and a plate control (four wells with $50 \mu \mathrm{L}$ of HBSS and $450 \mu \mathrm{L}$ of defined media). The plates were placed in an incubator at $37^{\circ} \mathrm{C}$ with $95 \%$ air and $5 \% \mathrm{CO}_{2}$.

Forty $h$ after the addition of the extracts, the cultures were rinsed once with Tris- $\mathrm{HCl}$ in $0.9 \% \mathrm{NaCl}$ (TBS, $0.05 \mathrm{M}$; $\mathrm{pH} 7.6$ ). The cultures were then fixed using $4 \%$ paraformaldehyde, $1 \%$ glutaraldehyde, and $0.2 \%$ picric acid in a $0.2 \mathrm{M}$ sodium acetate buffer (pH 5.0). After $2.5 \mathrm{~h}$, the wells were rinsed twice with TBS containing $0.25 \%$ Triton-X-100 for $5 \mathrm{~min}$. The wells were again rinsed twice with TBS. The cultures were then incubated with $10 \%$ normal goat serum (Gibco, Grand Island, NY) for $1 \mathrm{~h}$ and then rinsed three times for $5 \mathrm{~min}$ each with TBS. Rabbit anti-rat NSE (1:500) (Eugene Tech, Ridgefield Park, NJ) and 1\% normal sheep serum $(1: 1000)$ were added to the cultures for $1 \mathrm{~h}$. Three 5 - $\mathrm{min}$ rinses with TBS were followed by culture incubation in the avidin-biotin complex (ABC Elite kit; Vectastain, Vector Laboratories Inc., Burlingame, $C A$ ) diluted 1:10 000. The reaction was completed by incubating the cultures in a chromogen solution containing TBS, $0.05 \% 3-3$ 'diaminobenzidine, $2.5 \%$ nickel ammonium sulfate, and $0.003 \%$ hydrogen peroxide.

The plates were air dried, dehydrated, and then scored for the number of NSE neurons by an observer blinded to treatment history. Using a phase-contrast, inverted microscope Fluovert (Leitz, Leipsig, Germany) the center strip of each well was scanned from the top of the well to the bottom (approximately $21 \%$ of the total surface area). Neuronal cells were operationally defined as NSEir cells, which had a well-defined, thin process extending at least one half the diameter of the cell body. The mean NSEir cell counts from the eight replicate wells for each tissue extract, protein, and plate control served as the dependent measure of trophic activity. DA and DOPAC (expressed as ng/ $\mathrm{mg}$ protein) and number of NSEir cells in the cultures were analyzed using the $t$ test with comparisons made between the cocaine-exposed and vehicle pups. Values were considered significant if $p$ was less than 0.05 .

\section{RESULTS}

In utero cocaine exposure $(30 \mathrm{mg} / \mathrm{kg} / \mathrm{d})$ during gestational $\mathrm{d}$ $7-15$ resulted in a $46 \%$ reduction in striatal DA content assessed at postnatal d 4-6 $(t=2.31 ; p<0.05$ : Fig. 1, left $)$. The DA metabolite DOPAC was similarly reduced $(t=2.44 ; p<0.05)$.

Assessment of striatal trophic activity $40 \mathrm{~h}$ after addition of the extracts to mesencephalic cultures revealed that in utero cocaine exposure reduced, by $61 \%$, the number of NSEir neurons growing in culture $(t=4.81 ; p<0.01$ : Fig. 1 , right $)$. However, in utero cocaine exposure did not alter the trophic activity present in cerebellar extracts $(t=0.01 ; p=N S)$, the effects of which were reduced relative to the striatal effect in both the vehicletreated $(t=6.97 ; p<0.005)$ and cocaine-treated pups $(t=3.50$; $p<0.05)$. The growth effects of the cerebellar extracts were statistically similar to those observed in cultures containing an equivalent quantity of BSA (data not shown).

\section{DISCUSSION}

Our results indicate that cocaine exposure during early gestation significantly reduced striatal DA, DOPAC, and striatal

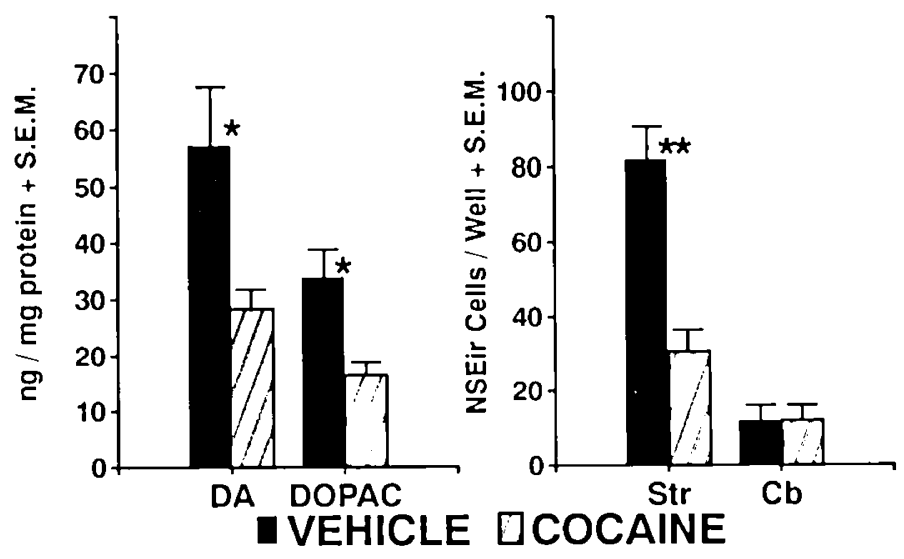

Fig. 1. The effect of prenatal cocaine on striatal DA, DOPAC, and NSEir cell counts in culture. Left. Levels of DA and DOPAC in the striatal tissue punches taken from 4- to 6-d-old rabbit pups after prenatal vehicle or cocaine exposure. Right, The number of NSEir neurons present in culture $40 \mathrm{~h}$ after incubation with striatal $(S t r)$ or cerebellar $(C b)$ extracts taken from 4- to 6-d-old rabbit pups exposed to vehicle or cocaine prenatally. $\left({ }^{*}=p<0.05 ;{ }^{* *}=p<0.01\right.$ : vehicle is cocaine exposure.)

trophic activity in the newborn rabbit. To our knowledge, this study represents the first report investigating the relationship between prenatal cocaine exposure during early gestation and postnatal neurotrophic activity.

Mesencephalic neurons growing at low densities in defined media die rapidly. Several laboratories $(21-26)$, including ours $(16,17,19,20,27-31)$, have demonstrated that the addition of striatal extracts containing trophic activity directed at mesencephalic neurons reduces this neuronal death rate and stimulates the growth of DA neurons. As seen in the present study, mesencephalic cultures incubated with striatal extracts from untreated animals reduced the neuronal death rate relative to the effects of extracts from the cerebellum or cultures incubated with. an equivalent quantity of BSA. This suggests that the striaturin, a "target structure" of mesencephalic neurons, contains trophic activity that supports the growth of mesencephalic neurons, whereas the cerebellum, which is not a target structure of the mesencephalon, does not support growth any meic than BSA The fact that cultures incubated with striatal extracts from rabbit pups exposed to cocaine prenatally contained fewer neurons therefore suggests that striatal trophic activity was reduced by in utero cocaine exposure. Whether or rot the observed reduction in striatal trophic activity was specific for DA neurons or other neurons in culture was not evaluated in this preliminary study because of the limited quantity of tissue available. However, in all of the studies we have performed to date, alterations in striatal trophic activity in low cell density cultures have been associaied with changes in indices of DA neuron growth $(16,17,19,20$, 27-31).

The reductions in striatal DA and its metabolite DOPAC are consistent with several recent reports. Prenatal cocaine exposure $(60 \mathrm{mg} / \mathrm{kg}$ intragastric; E8-22) of Wistar rats was associated (at P60) with decreased glucose metabolism in somatosensory and motor cortices, hypothalamus, nigrostriatal pathway, medial forebrain bundle, hippocampus, septum, and amygdala whencompared with controls (32). Prenatal cocaine exposure $(40 \mathrm{mg} /$ $\mathrm{kg} \mathrm{s.c.)}$ decreased spontaneous activity in dopaminergic celis in the substantia nigra pars compacta and the ventral tegmental area (33). Rats exposed to cocaine $(5 \mathrm{mg} / \mathrm{kg}$ s.c.) for their entire gestational period exhibited a $50 \%$ diminution of basal DA release when assessed on P21 (12). Cocaine exposure (30 mg/kg during E15-21) was also observed to reduce the rate-limiting enzyme in DA synthesis, tyrosine hydroxylase, in the siriatal matrix of rat pups assessed on P20, although striatal patch 
tyrosine hydroxylase was elevated (11). Cocaine exposure (10 $\mathrm{mg} / \mathrm{kg}$ ) between $\mathrm{d}$ E14-21 also reduced the number of DA reuptake sites when assessed at P42 (10). These various indices of DA neuron activity are also consistent with the increase in striatal $\mathrm{D}_{2}$ dopamine binding observed in rat pups after prenatal cocaine exposure $(40 \mathrm{mg} / \mathrm{kg})$, because reduced striatal DA is associated with an up-regulation of this receptor subtype $(19,34$, 35 ). Taken together, these data are consistent with a negative effect of prenatal cocaine on the development and maturation of the DA system.

Several investigators have observed that the development of neurons is dependent upon the availability of target-derived neurotrophic factors (36-38). Developing neurons compete for a limited quantity of target-derived factor. Those neurons that take up the factor survive to innervate their target. Those neurons that do not take up adequate amounts of this factor undergo what is referred to as "programmed cell death" or apoptosis. Indeed, the neuron death observed in culture may very well reflect programmed cell death (39). It is therefore possible that the cocaine-induced decrease in striatal-derived neurotrophic activity could lead to increased rates of programmed cell death and an associated underdevelopment of the DA system. It is also possible that the anesthetic effects of cocaine could have a direct effect on the development of the DA neuron, inasmuch as several authors have reported that the electrical activity of neurons plays a major role in their development (40).

The mechanism responsible for the effect of cocaine on DA development is unknown. Woods et al. (41) have reported that the administration of cocaine during pregnancy reduces fetal blood flow and oxygenation. Continued hypoxia could result in a variety of teratogenic effects that could directly influence the development of the DA system. However, the results from the present study also suggest that prenatal cocaine might indirectly affect the growth of DA neurons. If the development and maturation of mesencephalic DA neurons is dependent upon the availability of target-derived neurotrophic factors, the observed cocaine-induced reduction in this trophic activity may have been inadequate to support the growth of DA neurons during developrinent, leading to reductions in DA observed in our study as well às by others.

The present results therefore extend the observations of others that prenatai cocaine exposure negatively affects the DA system. The finding that prenatal cocaine exposure also affects trophic activity in the striatum may offer a new mechanism through which teratogenic effects on the DA system may occur. These alterations in DA and striatal trophic activity may underlie many of the developmental problems observed in animals and humans exposed to cocaine during pregnancy.

\section{REFERENCES}

1. Lester BM, Corwin MJ, Sepkoski C, Seıfer R, Peucker M, McLaughlin S Solub HL 1991 Neurobehavioral syndromes in cocaine-exposed newborn infants. Child Dev 62:694-705

2. Hurre RF, Maj MC, O'Donnelt KJ, Stanger CL, Killam AP, Gingras JL 1989 In utero cocaine exposure: observations of fetal behavioral state may predict net autal outcome. Am J Obstet Gynecol 161:685-690

3. Chac noff IJ, Burns WJ, Schnoll SH, Burns KA 1985 Cocaine use in pregnancy. $\therefore$ Engl J Med 313:666-669

4. Chasnoff IJ, Griffith DR, MacGregor S, Dirkes K, Burns KA 1989 Temporal patterns of cocaine use in pregnancy. JAMA 261:1741-1744

5. E.jen LN, Field TM, Bandstra ES, Roberts JP, Morrow C, Larson SK, Steele B.M 199 ! Perinatal cocaine effects on neonatal stress behavior and performance on the Brazelton scale. Pediatrics 88:477-480

6. In Bar A 1990 Development of infants of drug dependent mothers. J Child Psychol Psychiatry 31:911-920

7. Rodning C, Beckwith L, Howard J 1989 Characteristics of attachment organization and play organization in prenatally drug-exposed toddlers. Dev Psychopathol 1:277-289

8. Chasnoff IJ, Griffith DR, Freier C, Murray J 1992 Cocaine/polydrug use in pregnancy: two-year follow-up. Pediatrics 89:284-289
9. Chasnoff I, Griffith D. Azuma S 1992 Intrauterine cocaine/polydrug exposure: three year outcome. Pediatr Res 31:9A(abstr)

10. Pritchard GA, Byrnes JJ, Miller LG 1992 Prenatal cocaine exposure alters dopamine transporter binding in adult mice. Soc Neurosci Abstr 18:1456

11. Jackson D, Manley MS, Manley LD. Young SJ, Groves PM 1992 Effects of prenatal cocaine exposure on striatal tyrosine hydroxylase immunoreactivity. Soc Neurosci Abstr 18:366

12. Howard S, Blank D, Dao R, Blank CL 1992 Chronic pre and postnatal exposure to cocaine produces an alteration in the release of dopamine and acetylcholine in the developing rat pup. Soc Neurosci Abstr 18:365

13. Weese-Mayer DE, Klemka-Walden LM. Chan MK, Gingras JL 1991 Effects of prenatal cocaine exposure on perinatal morbidity and postnatal growth in the rabbit. Dev Pharmacol Ther 4:221-230

14. Weese-Mayer DE, Klemka-Walden LM, Barkov GA, Gingras JL 1992 Effects of prenatal cocaine on the ventilatory response to hypoxia in newborn rabbits. Dev Pharmacol Ther 18:116-124

15. Weese-Mayer DE, Barkov GA 1993 Effect of cocaine in early gestation: physiologic responses to hypoxia in newborn rabbits. Am Rev Respir Dis 148 (in press)

16. Carvey PM, Ptak LR, Lo ES, Lin DH, Buhrfiend CM, Goetz CG, Klawans HL 1991 Levodopa reduces the growth promoting effects of striatal extracts on rostral mesencephalic tegmentum cultures. Exp Neurol 114:28-34

17. Carvey PM, Ptak LR, Lin DH, Lo ES, Buhrfiend CM, Drucker GE, Fields JZ 1993 Alterations in striatal neurotrophic activity induced by dopaminergic drugs. Pharm Biochem Behav 46:195-204

18. McLaren A 1972 The embryo. In: Austin CR, Short RV (eds) Reproduction in Mammals. Embryonic and Fetal Development. Cambridge University Press, Cambridge pp $:-42$

19. Carvey PM, Kao LC, Tanner CM, Goetz CG, Klawans HL 1986 The effect of antimuscarinic agents on haloperidol induced behavioral hypersensitivity. Eur J Pharmacol 120:193-199

20. Carvey PM, Ptak LR, Kao LC, Klawans HL 1989 Striatal homogenates from animals chronically treated with haloperidol stimulate dopamine and GABA uptake in cultures of rostral mesencephalic tegmentum. Clin Neuropharmacol 12:425-434

21. Dal Toso R, Giorgi O, Soranzo C. Kirschner G, Ferrari G, Favaron M, Benvegnu D. Presti D, Vicini S, Toffano G. Azzone GF, Leon A 1988 Development and survival of neurons in dissociated fetal mesencephalic serum-free cell cultures: I. Effects of cell density and of an adult mammalian striatal-derived neuronotrophic factor (SDNF). J Neurosci 8:733-745

22. di Porzio U, Daguet MC. Glowinski J, Prochiantz A 1980 Effect of striata! cells on in vitro maturation of mesencephalic dopaminergic neurones grown in serum-free conditions. Nature 288:370-373

23. Prochiantz A, Daguet MC, Herbet A, Glowinski J 1981 Specific stimulation of in vitro maturation of mesencephalic dopaminergic neurones by striatal membranes. Nature 293:570-572

24. Hemmendinger LM, Garber BB, Hoffman PC, Heller A 1981 Target neuronspecific process formation by embryonic mesencephalic dopamine neurons in vitro. Proc Natl Acad Sci USA 78:1264-1268

25. Hoffman PC, Hemmendinger LM, Kotake C, Heller A 1983 Enhanced dopamine cell survival in reaggregates containing telencephalic target cells. Brain Res 274:275-281

26. Tomozawa Y, Appel SH 1986 Soluble striatal extracts enhance development of mesencephalic dopaminergic neurons in vitro. Brain Res 399:111-124

27. Carvey PM, McRae A, Ptak LR, Kao LC, Lo ES, Goetz CG, Tanner CM, Penn RD, Klawans HL 1990 Disappearance of a putative DA-neuron antibody following adrena! medulla transplantation: relationship to a striatalderived DA neuron trophic factor. Prog Brain Res 82:693-697

28. Kerns JM, Sierens DK, Kao LC, Klawans HL, Carvey PM 1992 Synaptic plasticity in the rat striatum following chronic haloperidol treatment. Clin Neuropharmacol 15:488-500

29. Carvey PM, Ptak LR, Nath ST, Sierens DK, Mufson EJ, Goctz CG, Klawans HL 1993 Striatal extracts from patients with Parkinson's disease promote dopamine neuron growth in mesencephalic cultures. Exp Neurol 120:149152

30. Carvey PM, Ptak LR, Lo ES, Klawans HL 1990 Homogenates of Parkinsonian striatum enhance DA-uptake in rat mesencephalic cultures relative to control striatum. Neurology 40(Suppl 1):402

31. Carvey PM, McRae A, Lint TF, Ptak LR, Lo ES, Goetz CG, Klawans HL 1991 The potential use of a dopamine neuron antibody and a striatal-derived neurotrophic factor as diagnostic markers in Parkinson's disease. Neurology 41(Suppl 2):53-60

32. Dow-Edwards DL, Freed LA, Fico TA 1990 Structural and functional effects of prenatal cocaine exposure in adult rat brain. Dev Brain Res 57:263-268

33. Minabe Y, Ashby CR, Heyser C, Spear LP, Wang RY 1992 The effects of prenatal cocaine exposure on spontaneously active midbrain dopamine neurons in adult male offspring: an electrophysiological study. Brain Res 586:152-156

34. Burt DR. Creese 1, Snyder SH 1977 Antischizophrenic drugs: chronic treatment elevates dopamine receptor binding in brain. Science 196:326-328

35. Scalzo FM, Ali SF, Frambes NA. Spear LP 1990 Weanling rats exposed prenatally to cocaine exhibit an increase in striatal D2 dopamine binding 
associated with an increase in ligand affinity. Pharmacol Biochem Behav 37:371-373

36. Maderdrut JL, Oppenheim RW, Prevette D 1988 Enhancement of naturally occurring cell death in the sympathetic and parasympathetic ganglia of the chicken embryo following blockade of ganglionic transmission. Brain Res 444:189-194

37. Oppenheim RW, Haverkamp LJ. Prevette D, McManaman JL, Appel SH 1988 Reduction of naturally occurring motoneuron death in vivo by a targetderived neurotrophic factor. Science 240:919-922
38. Lipton SA, Frosch MP, Phillips MD, Tauck DL, Aizenman E 1988 Nicotinic antagonists enhance process outgrowth by rat retinal ganglion cells in culture. Science 239:1293-1296

39. Manthorpe M, Skaper SD, Varon S 1981 Neuronotrophic factors and their antibodies: in vitro microassays for titration and screening. Brain Res 230:295-306

40. Mattson MP 1988 Neurotransmitters in the regulation of neuronal cytoarchitecture. Brain Res 472:179-212

41. Woods JR, Plessinger MA. Clarke KE 1987 Effect of cocaine on uterine blood flow and fetal oxygenation. JAMA 257:957-961 